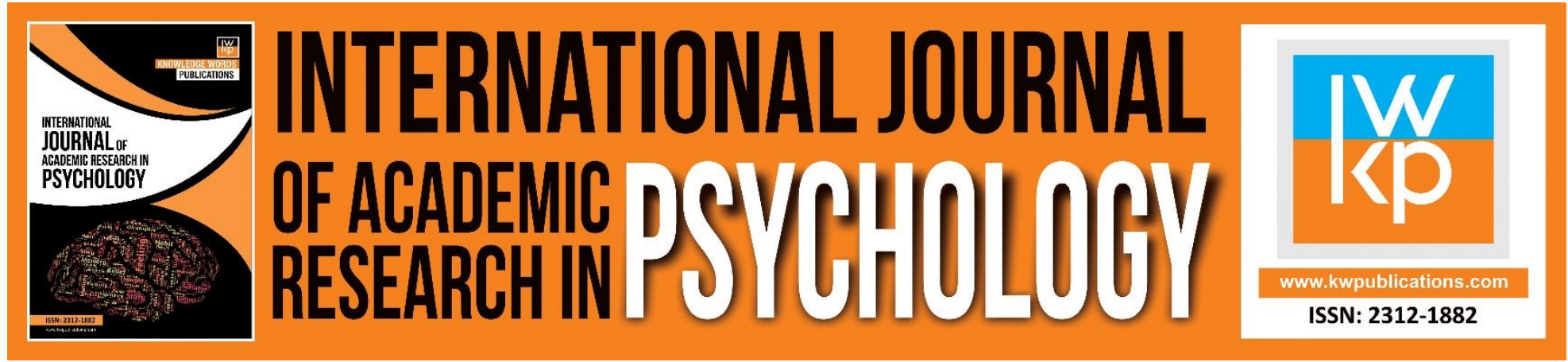

\title{
Stress and Depression in Destitute and Normal Females
}

\section{Anita Sharma}

To Link this Article: http://dx.doi.org/10.46886/IJARP/v1-i1/631

DOI:10.46886/IJARP/v1-i1/631

Received: 01 January 2014, Revised: 02 February 2014, Accepted: 10 March 2014

Published Online: 10 April 2014

In-Text Citation: (Sharma, 2014)

To Cite this Article: Sharma, A. (2014). Stress and Depression in Destitute and Normal Females. International Journal of Academic Research in Psychology, 1(1), 1-7.

Copyright: (c) 2014 The Author(s)

Published by Knowledge Words Publications (www.kwpublications.com)

This article is published under the Creative Commons Attribution (CC BY 4.0) license. Anyone may reproduce, distribute, translate and create derivative works of this article (for both commercial and non-commercial purposes), subject to full attribution to the original publication and authors. The full terms of this license may be seen at: http://creativecommons.org/licences/by/4.0/legalcode

Vol. 1, No. 1, 2014, Pg. 1 - 7

https://kwpublications.com/journals/journaldetail/IJARP

JOURNAL HOMEPAGE

Full Terms \& Conditions of access and use can be found at https://kwpublications.com/pages/detail/publication-ethics 


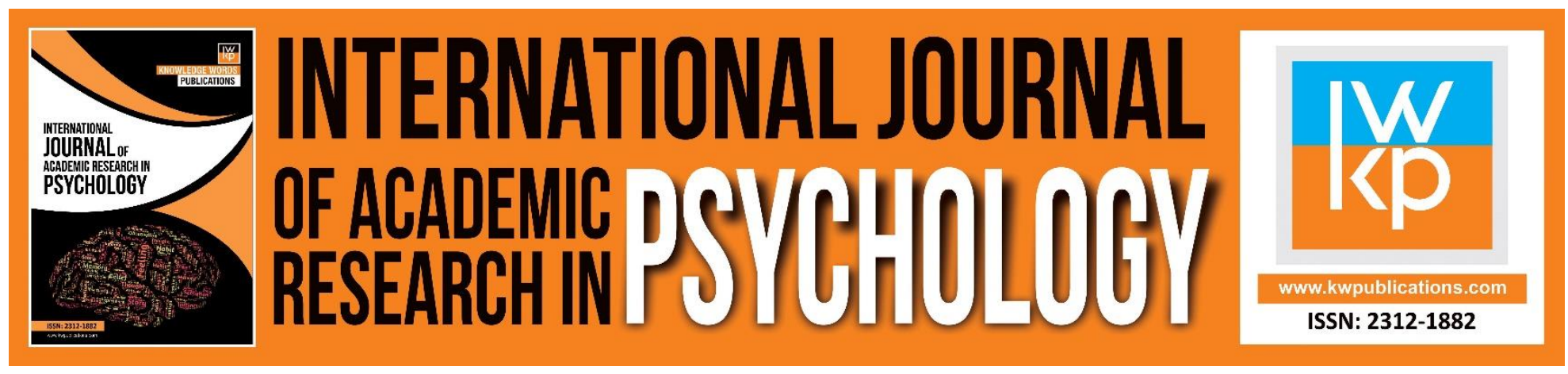

\title{
Stress and Depression in Destitute and Normal Females
}

\author{
Dr. Anita Sharma \\ Assistant Professor, Psychology Department, H.P. University Shimla-5
}

\begin{abstract}
The present study was aimed to explore the significance of differences if any between normal and destitute married females on their stress and depression levels. The females (35 normal and 35 destitute) were assessed on stress and depression by using ICMR Psychological stress questionnaire (Srivastava, 1991-92) and Beck depression inventory (1994). Data were analysed by using quantitative and qualitative analysis. Results have revealed the significant differences between normal and destitute females on stress ( $t=49.29 * *, P<.01)$ and depression $(t=50.20 * *, P<.01)$ i.e. destitute females have reported significantly higher level on stress and depression than normal females. Case studies have further authenticated the results. Overall, results indicate a great need to provide social, emotional and financial support to destitute females to promote their overall well-being and mental health by giving insight into their problems.
\end{abstract}

Keywords: Destitution, Destitute Females, Stress and Depression.

\section{Introduction}

Destitution describes lacking the means to meet the basic needs of shelter, warmth, food, water, and health. Destitution has become the term commonly used to refer the poverty experienced by asylum seeker and who without social emotional and financial support.

Destitution has become a serious offshoot of family problems in India. Women seem to be always at the receiving end of broken families. This phenomenon shows up not only in the economically backward families but in the well-off ones as well. The studies indicate that it was mostly against their will that women are resorting to the extreme step of taking shelter in some destitute home.

Destitute woman refers to a female without adequate support who is widowed, abandoned or left alone without care. "Destitute" in relation to a woman and widow means any female who has no independent source of livelihood or is not being looked after by any family member or relative and includes a divorced woman.

Destitution of women is found to be due to several social disadvantages that either reflect pre-existing ones or are the consequence of serious problems with cognition, affect, and behaviour in our society. Pre-existing disadvantages include poor education, living conditions and family relationships, specifically oppression, violence, sexual abuse, 
subordination and devaluation inherent in patriarchal oppression. As Bachrach (1988) stresses, women typically experience a variety of social disadvantages as a consequence of social oppression that contributes to their social disablement. Other social disadvantages may be seen as a consequence of the problems themselves: poverty, homelessness, stigmatization, exclusion from many aspects of 'normal life' and disrupted family and social networks all of which make destitute women marginalized and render them powerless. Personality disorders, sexual dysfunctions, and other types of maladjustment are also seen to be the reasons for destitution. Such psychological problems have been viewed as a product of oppression. The stress imposed by oppression can, and undoubtedly does, precipitate socially disabling disorders of cognition, affect, and behaviour. It was found that stress \& depression were positively correlated for homeless women who also suffered from the problems taking place in families (Ayerst \& Sandra, 1999).

Stress is an important issue and is growing rapidly in every facet of life. Now-a-days studies on stress are very essential in order to know its relation with relevant organizational factors responsible for productivity and performance. Stress is something which makes one feels uncomfortable. It creates imbalance and individual makes an effort to restore the state of balance.

Stress is the wear and tear. Our bodies experience as we adjust to our continually changing environment; it has physical and emotional effects on us and can create positive or negative feelings. As a positive influence, stress can help compel us to action; it can result in a new awareness and an existing new perspective. As a negative influence, it can result in feelings of distrust, rejection, anger and depression, which in turn can lead to health problems such as headaches, upset, stomach rashes, insomnia, ulcers, high blood pressure, heart disease and stroke.

The term stress has been defined variously by different psychologists. Selye (1974) says: "Stress is the non-specific response of body to any demand made on it". Black defined, "Stress refers to any force which physically or psychologically strains the coping mechanism of an organism". Ivan \& Matterson defined stress as "An adaptive response mediated by individual differences or psychological processes that is consequences of any external action, situation or event that places excessive psychological and physical demand upon a person". Robins defined stress as "A dynamic condition in which an individual is confronted with an opportunity, constrained or demand related to what he desires and for the outcome is perceived to be both uncertain and important".

The term depression covers a variety of negative moods and behavior changes. Some are normal mood fluctuations and other meet the definition of clinical problems. The mood change may be temporary or long-lasting. It may range from a relatively minor feeling of melancholy to a deep negative view of the world and an inability to function effectively.

Depression is an emotional state marked by great sadness and apprehension feelings of worthless and guilt, withdrawal from others, lees of sleep, appetite and sexual desire or less of interest and pleasure in usual activities.

There is some variation in the symptoms and signs of depression across the life span. Depression in children sometimes results in their being overly active and aggressive; in adolescents, it is sometimes manifested by negativism, antisocial behavior and a feeling of being misunderstood and in order adults, depression is often characterized by distractibility and memory loss. Furthermore, an individual seldom shows all the aspects of depression: the diagnosis is typically made if at least a few signs are evident, particularly a mood of profound 
sadness that is out of proportion to the person's life situation and a loss of interest and pleasure in previously an enjoyable activities.

Major depression is one of the most widespread of the disorders, with a life-time prevalence rate of between 4 and 5 percent (Weissman et al., 1988). The average age of onset is between forty and fifty and it is most common in women than in men. It is also more frequent among members of the lower socioeconomic classes (Hirschfeld and Cross, 1982).

\section{Objectives}

- To observe the level of stress in normal females.

- To observe the level of stress in destitute females.

- To observe the level of depression in normal females.

- To observe the level of depression in destitute females.

- To find out the significance of difference between the normal and destitute females on stress and depression levels.

\section{Hypotheses}

- There will be a significant difference between normal and destitute females On their stress level.

- There will be a significant difference between normal and destitute females on their depression level.

\section{Method}

Sample

The sample for this study consisted of 70 subjects (married females) out of which 35 were normal females and 35 were destitute females. The sample was selected through purposive sampling from Shimla city and Nari Seva Sadan at Mashobra, falling in the agegroup of 21-45 years. Most of the subjects were educated up to the high school standard. The education level of the subjects ranged between fifth to tenth standard.

\section{Tools Used}

1) ICMR Psychological Stress Questionnaire: This stress questionnaire is designed by, "Indian Council of Medical Research (ICMR)". The questionnaire was prepared by Fourth Advisory Committee (1991-92). The questionnaire was designed to assess psychological stress from various distressing or adverse social situations and was instructed to give their ratings for the severity of the left stress. Reliability of the measure of stress was estimated through Cronback-Alpha correlation $(r=.88)$, split half $(r=.88)$ and retest methods $(r=72)$. Reliability of the test was also examined through inter-relational consistency method $(r=.65)$. The content validity of the scale was examined through squared multiple correlation method which ranged from .18 to .53 with median value of .35 . Internal consistency of the tool was its seven subscales ranged from .24 to $.77(\mathrm{P}<.05)$. This further established the content validity of the measure.

2) Beck Depression Inventory (BDI, 1994): Hindi version of Beck's depression inventory (Rajwinder Kaur, 1994) was used for measuring attitude and symptoms associated with depression. It is a 21 items scale with the total score ranging from 0 to 63 . The 
original scale (Beck et al., 1961) is also a 21 items scale. The BDI is reported to possess adequate internal consistency (Upmanyu and Reen, 1990; Vredenberg, Krames and Flett, 1985). The psychometric characteristics of this questionnaire have been well documented in the Indian set up (Upmanyu and Reen, 1990). Kumar (1990) reported that the alpha co-efficient of the BDI was .88.

3) Case Study Method: Case study in psychology refers to the use of a descriptive research approach to obtain an in-depth analysis of a person, group, or phenomenon. A variety of techniques may be employed including personal interviews, directobservation, psychometric tests, and archives records. In psychology case studies are most often used in clinical research to describe rare events and conditions, which contradict well established principles in the field of psychology L.B. Christensen, 1994. Case studies are generally a single-case design, but can also be a multiple-case design, where replication instead of sampling is the criterion for inclusion (R. Yin, 1994).

\section{Procedure}

In the present study a percentage method was used in order to find out the quantity of stress and depression in normal and destitute females. The study was conducted on 35 normal females and 35 destitute females. To see the differences between normal and destitute females in stress and depression the t-test was also applied. To enhance the quality of the present study and for the better understanding of stress and depression in destitute females, qualitative method was used in this study.

\section{Results and Discussion}

Table - 1: t-test Analysis for Destitute and Normal Females on Stress and Depression

\begin{tabular}{|l|c|c|c|c|c|c|}
\hline \multirow{2}{*}{ Items } & \multicolumn{2}{|c|}{ Mean } & \multirow{2}{*}{ SD } & SED & t-ratio & \multirow{2}{*}{ Sig. } \\
\cline { 2 - 7 } & $\begin{array}{c}\text { Destitute } \\
\text { Females }\end{array}$ & $\begin{array}{c}\text { Normal } \\
\text { Females }\end{array}$ & Sem & & \\
\hline Stress & 119.17 & 11.71 & 9.07 & 2.18 & $49.29 * *$ & .01 \\
\hline Depression & 29.97 & 5.37 & 2.05 & 0.49 & $50.20 * *$ & .01 \\
\hline
\end{tabular}

Table-1 shows that there is a significant difference between normal and destitute females on stress and depression. As destitute females have significant higher mean on stress $(119.17 / 11.71)$ than normal females, hence the t-test was applied for testing the significance of mean difference and it is found to be significant at .01 level $(\mathrm{t}=49.29 * *, \mathrm{P}<.01)$. This represents that the destitute females are found to be more stressed as compared to the normal females. Studies have shown a higher occurrence of stressful life events in females without homes than in those with homes (North, Smith \& Spitznagel, 1994: Wright \& Weber, 1987). Even some studies have framed homelessness itself as a stressor (Goodman, Saxe \& Harvey, 1991). Homeless women reported significantly higher levels of stress and depression than the housed women (Banyard \& Graham-Bermann, 1998). Other research also shows that homeless females experience an exceptionally high number of stressful events throughout their life course, particularly in their transition to homelessness (Avraomov, 2000). 
Destitute females also have significant higher mean on depression (29.97/5.37) than normal females, hence the t-test was applied for testing the significance of the mean difference and it is also found to be significant at .01 level $(t=50.20 * *, P<.01)$. This represents that destitute females are found to be more depressed as compared to normal females. The incidence of depression among destitute women around the world is higher than among normal women and men (Brown, Melchior, Waite-O'Brien, \& Huba, 2002; Harvard Mental Health Letter, 2004; Kasen et al., 2003; Kaslow et al., 2000; Kneisl et al., 2004; Lilly, 2002; Wu \& Anthony, 2000). The rates of depression for homeless women are higher than those of nonhomeless women in the United States. Rates of depression among homeless women of all ages range from $18 \%$ to $37 \%$, whereas, the rate of depression in nonhomeless women in the United States is 1.9\% (Galaif, Nyamathi, \& Stein, 1999; Wu \& Anthony, 2000).

\section{Conclusion}

- There is a significant difference between normal and destitute females on their stress level i.e. destitute females have reported significantly higher level of stress as compared to normal females.

- There is a significant difference between normal and destitute females on their depression level i.e. destitute females have reported significantly higher level of depression as compared to normal females.

\section{References}

Avraomov, D. (2000). Housing Exclusion and Homelessness. Strasbourg: Council of Europe.

Ayerst, Sandra, L. (1999). Depression and stress in homeless. Journal of Adolescence, 34, 567675.

Bachrach, L. L. (1988). Chronically mentally ill women - an overview of service delivery issues in L.L. Bachrach and C.C. Nadelason (Eds) Treating Chronically mentally ill women, American Psychiatric Press, Washington D.C.

Banyard, V. L., \& Graham-Bermann, S. (1998). Surviving poverty: Stress and coping in the lives of housed and homeless mothers. American Journal of Orthopsychiatry.

Beck, A. T., Ward, C. H., Mendelson, M., Mock, J., \& Erbaugh, J. (1961). An inventory for measuring depression. Archives of General Psychiatry, 4, 561-571.

Brown, V. B., Melchior, L. A., Waite-O'Brien, N., \& Huba, G. J. (2002). Effects of womensensitive, long-term residential treatment on psychological functioning of diverse populations of women. Journal of Substance Abuse Treatment, 23, 133-144.

Christensen, L. B. (1994). "Experimental methodology" (6 ${ }^{\text {th }}$ ed.), Simon \& Schuster: Needham Heights, MA.

Goodman, L. A., Saxe, L., \& Harvey, M. (1991). Homelessness as psychological trauma: Broadening perspectives. American Psychologist, 46, 1219-1225.

Harvard Mental Health Letter. (May 2004). Women and depression. How biology and society may make women more vulnerable to mood disorders.

Hirschfeld, R. A., \& Cross, C. K. (1982). Epidemiology of affective disorders. Archives of General Psychiatry, 39, 35-46.

Kasen, S., Cohen, B., Chen, H., \& Castille, D. (2003). Depression in adult women: Age changes and cohort effects. American Journal of Public Health, 93, 2061-2064. 
Kaslow, N., Thompson, M., Meadows, L., Chance, S., Puett, R., Hollins, L., \& Kellermann, S. (2000). Risk factors for suicide attempts among African American women. Depression \& Anxiety, 12, 13-20.

Kneisl, C., Wilson, H., \& Trigoboff, E. (2004). Contemporary psychiatric mental health nursing. Upper Saddle River, NJ: Pearson-Prentice Hall.

Kumar \& Patel, S. (1990). Research study of women showing high and low adjustment in marriage. Journal of Personality and Clinical Psychology, 6, 73-76.

Lilly, E. (2002). Women and depression: Not just -the blues. Alabama Nurse, 29(1), 24.

North, C. S., Smith, E. M., \& Spitznagel, E. L. (1994). Violence and the homeless: An epidemiologic study of victimization and aggression. Journal of Traumatic Stress, 7, 95-110.

Kaur, R. (1994). Depression at adolescence: Co-relates attribution and coping strategies. Department of Psychology, Punjab University, Chandigarh.

Selye, H. (1974). Stress with distress. Philadelphia New York: J.B. Lippincott.

Upmanyu, V. V., \& Reen, M. (1990). A study of popular self report measures of depression. Journal of Personality and Clinical Studies, 6(2), 159-164.

Verdenburg, S. K., \& Fistt, F. C. (1985). Re-examining the Beck Depression Inventory. Psychological Reports, 56(3), 767-778.

Wright, J. D., \& Weber, E. (1987). Homelessness and health. Washington, DC: McGraw-Hill.

$\mathrm{Wu}$, L. T., \& Anthony, \& J. C. (2000). The estimated rate of depressed mood in US adults: Recent evidence.

Yin, R. (1994). "Case study research: Design and method" (2 ${ }^{\text {nd }}$ ed.). Sage Publishing: Beverly Hills, CA. 